\title{
Membaca Sandur Bojonegoro dan Sandur Tuban
}

\author{
J. Catur Wibono, Trisno Tri Susilowati, dan M. Ali As'ad ${ }^{*}$ \\ Jurusan Teater, Fakultas Seni Pertunjukan, Institut Seni Indonesia Yogyakarta
}

\begin{abstract}
Reading Bojonegoro and Tuban's Sandur Performances. Sandur performance is a form of social and cultural activities of agrarian society. This study focuses on the difference between Bojonegoro and Tuban's Sandur performances. This performance is a form of expression patterns of thought and feeling into a tangible folk art. It will compare the themes of the stories, the actors, makeup and fashion, properties, music accompaniment, stages, time of performances and audiences. Comparative study of aesthetic forms an important aspect in order to analyze a traditional theater. Based on the research concluded that Sandur performance is one way to present the creative ideas with aesthetic value. Performing of Sandur also has a complexity of meaning contained therein.
\end{abstract}

Key Words: Sandur, traditional drama, Bojonegoro, Tuban.

\section{Pendahuluan}

Kesenian Sandur adalah jenis kesenian tradisional yang berbentuk dramatari dengan mengambil cerita lokal yang menggambarkan kehidupan masyarakat sehari-hari (Winarti, 2005:1). Kesenian ini tumbuh dan berkembang sebagai aktivitas sosial budaya masyarakat agraris, yakni masyarakat yang hidup dengan pola dan sistem pertanian sebagai sumber kehidupan mereka. Hal ini dapat diketahui dari bentuk pertunjukan dan isi cerita yang bertema tentang aktivitas pertanian seperti mencari lahan pertanian untuk bercocok tanam, membajak ladang atau sawah, menanam, memanen hasil pertanian serta persoalan-persoalan sosial masyarakatnya. Pertunjukan Sandur tumbuh dan berkembang di beberapa daerah di Jawa Timur, antara lain di kabupaten Bojonegoro, Tuban, Lamongan dan Nganjuk. Menurut cerita tutur, kesenian Sandur sudah ada sejak masa penjajahan Belanda. Bentuk kesenian ini dipercaya oleh masyarakat berasal dari permainan anak-anak yang kemudian berkembang menjadi sebuah produk kesenian yang bertumpu pada upacara ritual. Sebutan 'Sandur' berasal dari berbagai versi. Sebuah sumber mengemukakan bahwa kata Sandur berasal dari kata isan yang berarti selesai panen dan dhur yang berarti ngedhur atau semalam suntuk. Sumber lain menjelaskan bahwa Sandur berasal dari bahasa Belanda, yaitu soon yang berarti anak-anak dan door yang berarti meneruskan. Sumber yang lain juga mengemukakan bahwa Sandur terdiri dari berbagai cerita yang disebut ngedur, artinya kesenian itu terjadi karena berisi tentang berbagai macam cerita yang tidak akan habis sampai pagi. Selain itu ada juga yang memaknai Sandur merupakan akronim dari kata beksan yang berarti tarian dan mundur, yaitu mundur, yakni adegan gerak maju-mundur dalam pertunjukan Sandur.

Keberadaan kesenian Sandur di beberapa daerah dipengaruhi oleh latar belakang masyarakatnya. Latar sosial budaya masyarakat itu telah menciptakan persamaan dan perbedaan baik dalam hal bentuk, gaya dan fungsinya. Persamaan dan perbedaan tersebut juga disebabkan oleh faktor sosio-kultural masyarakat yang memiliki dinamika perubahan yang berbeda-beda. Sedyawati (1981: 40) menegaskan bahwa perubahan-perubahan masyarakat dan budaya telah menyebabkan teater tradisi mengalami perubahan-perubahan bentuk maupun konsepnya. Hal itu juga terdapat pada keragaman kesenian Sandur yang disebabkan oleh perubahan yang terjadi dalam masyarakat pendukungnya. Keragaman kesenian Sandur dapat terlihat pada kesenian Sandur yang terdapat di Desa Ledok Kulon, Kecamatan Bojonegoro, Kabupaten Bojonegoro dan di Dukuh Randu Pokak, Desa Prunggahan Kulon, Kecamatan Semanding, Kabupaten Tuban. Kedua daerah tersebut masih memiliki persamaan sosial budaya karena letak geografis yang berdekatan, sehingga memungkinkan adanya persamaan unsur-unsur

* Alamat Korespondensi: Jurusan Teater ISI Yogyakarta, Jln. Prangtritis Km. 6,5 Yogyakarta.

Tel. (0274) 375380.E-mail: caturwibowo@yahoo.com. 
dalam bentuk kesenian Sandur. Namun dalam kesenian Sandur juga memiliki perbedaan pada unsur-unsur dan bentuk penyajiannya.

Kasim (1981: 110) mengatakan bahwa kesenian tradisional adalah suatu bentuk seni yang bersumber dan berakar serta telah dirasakan sebagai milik sendiri oleh masyarakat lingkungannya. Pengolahannya didasarkan atas cita-cita masyarakat pendukungnya. Cita rasa di sini mempunyai pengertian yang luas, termasuk "nilai kehidupan tradisi", pandangan hidup, pendekatan falsafah, rasa etis dan estetis, serta ungkapan budaya lingkungan.” Selanjutnya Kasim (1986: 173-174) mengemukakan bahwa bentuk teater tradisional adalah teater yang berwujud sederhana, spontan, menyatu (akrab) dengan kehidupan masyarakat dan diwariskan dari generasi ke generasi dalam jangka waktu yang panjang. Pendapat tersebut memberikan uraian tentang proses pembentukan dan nilai-nilai yang terkandung dalam entitas seni tradisi, yakni nilai-nilai yang terdapat pada bentuk karya atau produk kesenian yang terdapat pada suatu masyarakat.

Sandur sebagai produk sosial budaya memiliki berbagai fungsi, yaitu untuk memenuhi kebutuhan masyarakat seperti fungsi ritual, sebagai sarana komunikasi sosial, dan fungsi hiburan. Berbagai fungsi kesenian Sandur ditentukan oleh perubahan kebutuhan masyarakat pendukungnya. Perubahan-perubahan terjadi bukan semata-mata karena pemilikan suatu jenis tradisi menjadi luas, tetapi bisa pula karena manusia-manusia pendukung kebudayaan daerah itu sendiri telah berubah. Hal tersebut terjadi juga pada bentuk kesenian Sandur yang terdapat di Desa Ledok Kulon, Kecamatan Bojonegoro, Kabupaten Bojonegoro dan Sandur yang terdapat di Dukuh Randu Pokak, Desa Prunggahan Kulon, Kecamatan Semanding, Kabupaten Tuban. Alasan pemilihan objek kajian pada pertunjukan Sandur Bojonegoro dan Tuban, selain keunikan pada pertunjukannya juga karena dari dua bentuk kesenian tersebut memiliki unsur-unsur sejajar yang dapat diperbandingkan. Dari hasil kajian kedua bentuk kesenian Sandur tersebut, dapat diketahui unsur persamaan dan perbedaan yang bisa diklasifikasikan secara sistematis serta nilai khas dari masing-masing bentuk.

\section{A. Desa Ledok Kulon Bojonegoro}

Kabupaten Bojonegoro merupakan daerah yang berada di perbatasan Provinsi Jawa Timur dan Jawa Tengah. Bojonegoro terletak kurang lebih $250 \mathrm{Km}$ ke barat dari Surabaya dan kabupaten ini tepatnya bersebelahan dengan Kabupaten Blora, Provinsi Jawa Tengah. Kabupaten Bojonegoro yang berada di perbatasan dua propinsi tersebut mengakibatkan terjadinya percampuran dua subkebudayaan, yakni Jawa Tengah dan Jawa Timur. Hal ini tampak pada dialek yang digunakan dalam percakapan sehari-hari. Idiom em/ -nem (-mu) dan léb (lah/sih) yang biasa digunakan masyarakat Blora, Jawa Tengah dapat ditemukan pula pada masyarakat Bojonegoro. Misalnya kata Omah-em (rumahmu) atau untu-nem (gigimu), dan kalimat, "Gak ngono léh!" (tidak begitulah). Idiom gak (tidak) dan penekanan pada kata yang terkesan hiperbola, misalnya padang (terang) menjadi puadang (sangat terang) yang khas digunakan oleh masyarakat Jawa Timur pada umumnya juga ditemukan pada masyarakat di daerah ini.

Desa Ledok Kulon adalah salah satu desa yang berada di wilayah Kecamatan dan Kabupaten Bojonegoro, tempat kesenian Sandur berada. Percampuran antara dua subkebudayaan dapat dilihat pada masyarakat Desa Ledok Kulon ini. Desa Ledok Kulon terletak $2 \mathrm{~km}$ sebelah barat dari pusat Bojonegoro. Masyarakat Ledok Kulon dahulunya mayoritas bermata pencaharian sebagai petani. Namun karena terjadi pergeseran lahan pertanian dan pemekaran wilayah kota, lambat laun banyak warga masyarakat yang berganti mata pencaharian dengan membuat industri kecil, seperti industri batu bata dan tahu. Mata pencaharian lain yang juga ditekuni oleh sebagian masyarakat Ledok Kulon adalah sebagai buruh pabrik, Pegawai Negeri Sipil, penarik becak, dan bidang wiraswasta lainnya. Jenis kesenian selain Sandur yang masih lestari di desa tersebut antara lain tayub, wayang kulit, dan hadrah. Di samping itu, jenis musik yang digemari masyarakat adalah dangdut dan pop. Kesenian-kesenian tersebut dapat dinikmati dengan berbagai media, antara lain: televisi, VCD player, dan pertunjukan secara langsung. Letak desa Ledok Kulon yang dekat dengan pusat perkotaan sangat memungkinkan perilaku masyarakatnya terkena imbas kemajuan 
budaya perkotaan (modern). Meskipun demikian, banyak pula ditemui perilaku masyarakat yang tradisional.

Pergeseran pola kehidupan yang bersifat tradisional dan modern ini tampak pada perilaku warga masyarakat dewasa dan remaja, sedangkan warga yang sudah tua secara umum masih memegang pola tradisi yang turun-temurun. Cara berpakaian yang disesuaikan dengan trend-mode memberi gambaran bahwa remaja Desa Ledok Kulon sudah sangat terpengaruh oleh peradaban perkotaan. Orang-orang yang tergolong usia tua masih setia dengan pakaian tradisi dan perilaku yang kental dengan ke-jawa-annya. Misalnya perempuan tetap menggunakan kain jarit, kebaya, dan kerudung.

Perkembangan kondisi masyarakat Ledok Kulon telah menjadikan masyarakat bersifat heterogen. Artinya berbagai macam budaya dan pandangan hidup telah mewarnai kehidupan masyarakat Ledok Kulon yang dahulu hanya mengenal kebudayaan dan pandangan hidup Jawa agraris. Havilan (1988: 3) mengatakan bahwa terjadinya pertumbuhan masyarakat disebabkan oleh adanya adaptasi masyarakat, yakni melalui kecenderungan untuk meniru kebiasaan yang tampak baik. Lebih lanjut perubahan tersebut juga didukung oleh peranan generasi muda yang rentan terhadap pengaruh teknologi informasi modern, seperti televisi dan internet. Mereka cenderung meniru busana, kelakuan, dan pola hidup idola mereka. Keteguhan masyarakat untuk tetap bertahan pada nilai-nilai tradisi dan agama di antara laju perubahan peradaban menginspirasi para pemuka masyarakat dan agama (khususnya) untuk meningkatkan kualitas masyarakat. Setiap kelompok warga (RW) di desa yang mayoritas agama Islam ini memiliki kelompok atau jama'ah pengajian ataupun jama'ah tablil. Kegiatan-kegiatan ini diharapkan dapat menjadi penyeimbang bahkan penyaring atas informasi, budaya asing dan perubahan peradaban yang kurang menguntungkan. Menurut pendapat Pramudjito, seorang seniman Sandur Bojonegoro, masyarakat Islam di Ledok Kulon semestinya mendapat penjelasan dan pengkajian ajaran agama Islam secara lengkap meliputi ajaran syari'at, hakikat hingga ma'rifat. Ditambahkan pula oleh narasumber yang sama, bahwa jama'ab Islam pada umumnya kurang memahami hakikat ke-islamannya. Hal ini mengakibatkan fanatisme yang berlebihan. Kenyataan ini menutup pemahaman dan kemajuan umat itu sendiri. Lebih fatal lagi jika keadaan ini membawa pada proses perpecahan dan pertikaian antargolongan umat beragama. Gejala tersebut berimbas pula pada kesenian Sandur.

Pada awal kebangkitannya kembali pada tahun 1990-an Sandur tidak dapat diterima oleh golongan Islam yang memegang teguh fanatisme Islam. Alasan utama pertentangan tersebut karena di dalam Sandur terdapat unsur-unsur yang bertentangan dengan nilai-nilai ajaran Islam dan mengandung ajaran-ajaran mistik Jawa. Berdasarkan wawancara dengan Pramujito, kejadian intrance pada adegan jaranan, karena kerasukan roh halus dianggap perbuatan yang bersekutu dengan setan atau syirik. Meskipun demikian mayoritas masyarakat yang kurang memperhatikan hal tersebut menyambut dengan antusias "kebangkitan kembali" Sandur di tengahtengah masyarakat Ledok Kulon. Masyarakat Desa Ledok Kulon masih percaya pada hal- hal yang bersifat sakral atau gaib, misalnya dengan acara ritual sedhekah bum atau nyadran (bersih desa) dan slametan (selamatan) dengan mengundang para warga atau tetangga untuk berdoa bersama. Ritual ini bertujuan agar hajat hidup masyarakat atau seseorang yang memiliki hajat dapat berjalan dengan lancar dan tanpa halangan apapun, serta memperoleh hasil yang diharapkan. Tinjauan pada latar belakang sosio-kultural masyarakat di atas dapat memberikan keterangan bahwa masyarakat di desa Ledok Kulon masih memiliki pandangan hidup sesuai dengan nilai-nilai budaya Jawa. Mereka masih tetap melestarikan budaya, tata susila, simbol-simbol dan ajaran mistik Jawa. Kesenian Sandur yang berkembang dalam masyarakat juga tampak jelas membawa nilai-nilai tersebut.

\section{Bentuk Pertunjukan Sandur Ledok Kulon}

Tradisi rangkaian pertunjukan Sandur Desa Ledok Kulon Kecamatan Bojonegoro biasanya diawali dengan kegiatan pra pertunjukan yang berupa proses ritual setrén, yakni memintakan berkah dari leluhur (dhanyang), khususnya untuk properti pertunjukan tertentu, yakni jaranan (kuda kepang), tali tambang untuk adegan atraksi 
kalongking, pecut (cemeti) untuk menyadarkan penari jaranan yang ndadi, serta nama-nama Tukang Njaran dan Tukang Ngalong. Properti pertunjukan tersebut dimasukkan atau diinapkan di dalam cungkup (makam leluhur) beserta kelengkapan sesaji berupa kemenyan atau dupa, kembang setaman (aneka bunga), dan ulu wetu (hasil bumi), berupa padi, pisang dan buah-buahan lainnya. Tujuan umum dari ritual setrén adalah agar pertunjukan Sandur yang akan dilaksanakan dapat berjalan dengan lancar. Tujuan secara khusus yakni agar properti yang akan digunakan pada saat pertunjukan mendapat berkah atau memiliki daya magis, serta tidak mencelakai si pemakai. Tempat yang digunakan untuk nyetrékna (men-setrén-kan) adalah di cungkupl makam Ki Andhong Sari, seorang cikal-bakal atau sing mbahureksa (yang menguasai secara gaib) desa tersebut. Jika Sandur diadakan di desa lain, tempat untuk ritual tersebut

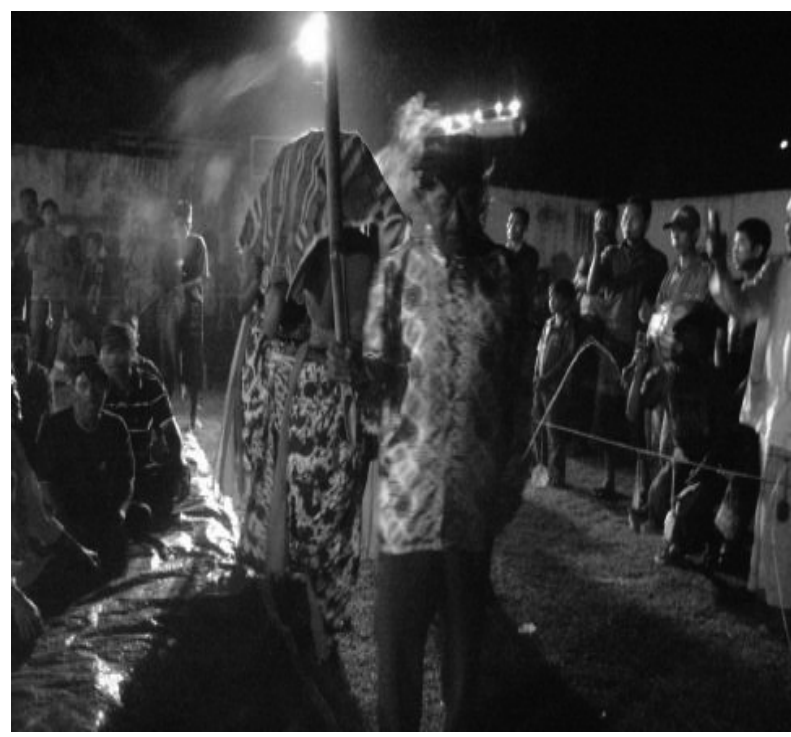

Gambar 1. Tokoh Germo Saat memimpin pertunjukan Sandur Bojonegoro (Repro: Masnun, 2008).

Prosesi pertunjukan Sandur di Ledok Kulon Bojonegoro cukup sederhana, yakni dibagi menjadi tiga bagian, yaitu (1) bagian pembuka; (2) bagian cerita dan (3) bagian penutup. Bagian pembuka terdiri dari tembang-tembang pembuka, berias, tari Jaranan dan Nggundhisi. Bagian cerita terdiri dari pertunjukan drama yang diperankan oleh lima tokoh, yakni Pethak, Cawik, Balong, Tangsil dan Germo serta tarian jaranan yang dilakukan secara khusus oleh Tukang Njaran dengan iringan tembang para Panjak Hore. Bagian penutup ditandai dengan adegan atraksi kalongking. Dewasa ini durasi pertunjukan Sandur hanya sekitar adalah cungkup di desa yang ditempati pentas. Pertunjukan dimulai dengan kemunculan peran Germo, yang memimpin upacara pendhayangan. Pendhanyangan adalah upacara membakar kemenyan dan sesaji cok-bakal di sudut timur laut arena blabar janur kuning, arena pertunjukan yang berbentuk bujur sangkar. Setelah itu, pada malam harinya dilaksanakan pertunjukan Sandur. Soedarsono (2001:123) menerangkan bahwa bentuk kesenian tradisional pada umumnya adalah sederhana dan mengandung nuansa sakral. Hal tersebut tampak pada kostum, properti yang digunakan, dan fungsinya sebagai sarana ritual. Sebagaimana keterangan tersebut, bentuk kesenian Sandur pun memiliki sifat yang sederhana dan bernuansa sakral dengan adanya adegan tari jaranan yang dilakukan dengan proses ndadi, serta mengadakan upacara ritual sesaji.

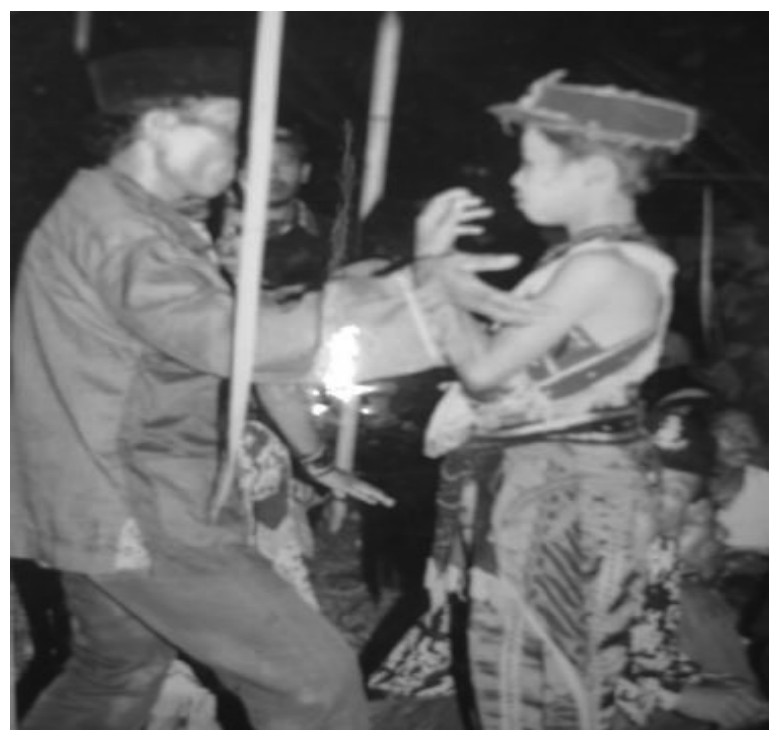

Gambar 2.Tokoh Germo Saat memimpin pertunjukan Sandur Tuban (Repro: Sakrun, 2007).

dua sampai tiga jam yakni jam delapan sampai jam sepuluh malam. Pada era tahun 1950-an sampai 1960-an durasi pertunjukan memakan waktu sekitar enam sampai tujuh jam yang dimulai dari jam sepuluh malam hingga menjelang subuh. Perlu ditambahkan pula bahwa Sandur biasanya dipentaskan pada malam Kamis Pahing dan tidak boleh menyelenggarakan pentas pada malam Jum'at Legi. Alasan pelarangan ini karena hari Jum'at Legi dipercayai oleh masyarakat Ledok Kulon sebagai hari naas desa tersebut.

Pertunjukan Sandur dimulai oleh Panjak Oré dengan menyanyikan tembang pembuka yang 
dipimpin oleh Germo. Tembang yang dinyanyikan antara lain, Bismillah, Ilir Gantu, Aja Hara-Biru kemudian Tulak Kala. Apabila langit mendung dan dimungkinkan hujan akan turun, dinyanyikan tembang Mendhung Sepayung. Setelah tembangtembang tersebut dinyanyikan, biasanya salah satu tukangnjaran segera ada yang $n$ dadi dan dimulailah tari jaranan. Jika belum ada yang ndadi kemudian dinyanyikan tembang Sulur Pandan. Adegan tari Jaranan di awal pertunjukan ini bertugas untuk mengantar para pemeran untuk berias di suatu tempat, biasanya di rumah penanggap pertunjukan Sandur. Adegan tersebut diiringi dengan tembang Kembang Luntas. Pada adegan ini para pemeran dijemput oleh perias yang membawa sebuah obor. Para pemeran keluar dengan dipimpin oleh perias. Jaranan mengikutinya hingga keluar dari arena pula. Adegan Jaranan disesuaikan dengan tembang iringannya, yakni mbesa (menari) dengan iringan tembang Lé li lé lo, Kembang Gempol, Mubeng blabar (mengitari arena pertunjukan) dengan iringan tembang Kembang Johar, Njaluk Ngombé (minta minum) diiringi dengan tembang Kembang Jambe, Njaluk Leren (minta berhenti), dengan iringan Kembang Durén, dan proses penyadarannya diiringi tembang Kembang Jambu yang menggambarkan jaranan minta tidur. Ngideri atau mubeng blabar bertujuan untuk mengamankan blabar janur kuning dari desakan para penonton yang dapat merusak blabar. Bagian ini jaranan mengitari blabar dari sisi luar. Adegan ini hanya dilakukan pada awal pertunjukan.

Tari jaranan dilakukan pada bagian cerita atau pada saat sajian drama, sedangkan adegan mubeng blabar dilakukan di dalam arena blabar janur kuning. Tari jaranan berakhir dengan ditandai Tukang Njaran sadar. Tembang-tembang yang dilantunkan selanjutnya adalah tembangtembang yang menggambarkan kegiatan para penari berias, antara lain tembang Kembang Gambas menggambarkan para pemeran mulai berias, tembang Pitek Lancur menggambarkan saat memakai bedak, tembang Kembang Kawis menggambarkan saat membuat alis, tembang Kembang Laos menggambarkan saat membuat kumis, tembang Pitik Lurik menggambarkan saat memakai kain jarit, tembang Jaran Dhawuk menggambarkan saat memakai sabuk (ikat pinggang), tembang Kembang Semboja menggambarkan saat memakai konca, dan tembang Kembang Térong menggambarkan para pemain memakai irah-irahan. Setelah tembangtembang tersebut dinyanyikan, biasanya para pemeran sudah siap untuk kembali ke arena pertunjukan.

Sekembalinya pemeran ke arena pertunjukan diiringi dengan tembang Kembang Otok. Para pemeran memasuki arena dengan dikerudungi dan diantar oleh perias dengan membawa obor, kemudian obor tersebut diserahkan kepada Germo. Adegan berikutnya, para pemeran dipimpin oleh Germo mengelilingi blabar janur kuning dengan iringan tembang Surak Horé. Mereka mengelilingi blabar tanpa menari, hingga sampai ke tempat semula, yakni di sisi utara menghadap ke timur.

Adegan selanjutnya adalah Germo Nggundhisi. Germo menceritakan proses turunnya empat puluh empat bidadari ke bumi. Bidadaribidadari tersebut merasuk ke tubuh tokoh-tokoh dalam pertunjukan Sandur, antara lain: bidadari bernama Dewi Wilutomo merasuki tubuh tokoh Pethak, Dewi Drustonolo ke tubuh tokoh Balong, Gagar Mayang ke tubuh tokoh Tangsil, Dewi Suprobo ke tubuh tokoh Cawik, dan Irim-Irim pada Germo, Panjak Oré, Panjak Kendhang, Panjak Gong,Kalongking, Tukang Njaran, dan lain sebagainya. Nggundhisi ini diakhiri dengan sebuah kode untuk meminta gending atau tembang yang harus dilantunkan, seperti dalang meminta gending pada akhir Janturan.

\section{B. Desa Prunggahan Kulon Kabupaten Tuban}

Kabupaten Tuban merupakan salah satu kota tua yang berada di wilayah pesisir pantai utara bagian barat Provinsi Jawa Timur. Daerah yang secara langsung berada pada perbatasan dengan kabupaten Rembang dan Blora, Provinsi Jawa Tengah. Di sebelah timur berbatasan dengan Kabupaten Lamongan. Sementara di sebelah selatan bersebelahan dengan Kabupaten Bojonegoro. Luas wilayah kabupaten Tuban 183.994.561 Ha dan wilayah laut seluas 22.068 $\mathrm{km}^{2}$. Letak astronomi Kabupaten Tuban pada koordinat $111^{\circ} 30^{\prime}-112^{\circ} 35^{\prime}$ BT dan 6o 40' - 7o 18 ' LS. Panjang wilayah pantai $65 \mathrm{~km}$. Ketinggian daratan di kabupaten Tuban berkisar antara 0-500 mdpl. Sebagian besar wilayah Kabupaten Tuban beriklim kering dengan kondisi bervariasi dari agak kering sampai sangat kering yang berada di 19 kecamatan sedangkan yang beriklim agak 
basah berada pada satu kecamatan. Kabupaten Tuban berada pada jalur Pantura dan pada deretan pegunungan Kapur Utara. Pegunungan Kapur Utara di Tuban terbentang dari Kecamatan Jatirogo sampai Kecamatan Widang dan dari Kecamatan Merakurak sampai Kecamatan Soko. Kabupaten Tuban lebih dikenal sebagai daerah pesisir yang memiliki pola hidup masyarakat dan kebudayaan yang berbeda dengan masyarakat non-pesisir. Konsekuensi atas hal tersebut dapat berpengaruh pada setiap aspek kehidupan masyarakatnya, seperti pada aspek sosiologis dan budaya yang memiliki identitas tersendiri. Masyarakat pesisir pada umumnya memiliki karakter dan sifat terbuka pada hal-hal baru yang memungkinkan terjadinya interaksi yang lebih dinamis pada seluruh aspek kehidupannya.

Di sebelah selatan Tuban, kira-kira berjarak sekitar 3 kilometer dari arah pusat kota, tepatnya di daerah Kecamatan Semanding, terdapat Desa Prunggahan Kulon, yakni salah satu desa yang terdapat kesenian Sandur yang masih terjaga keberadaannya. Keberadaan kesenian pertunjukan tradisional ini menunjukkan kepedulian masyarakat pendukungnya terhadap budaya yang dimiliki. Secara geografis di bagian barat Desa Prunggahan Kulon bersebelahan dengan Desa Jadi. Bagian timur berbatasan langsung dengan Desa Prunggahan Wetan dan Desa Bektiharjo, sebelah selatan berbatasan dengan Desa Gesikan kecamatan Grabagan, sedangkan di bagian utara berbatasan dengan Desa Kembang Bilo, Kecamatan Tuban dan Desa Tegalgung.

Sebagian besar masyarakat Prunggahan Kulon memiliki mata pencaharian sebagai petani, buruh tambang batu kapur dan wiraswasta. Selain itu, sebagian kecil ada yang berprofesi sebagai Pegawai Negeri Sipil, aparat TNI, mantri/perawat dan guru. Berdasarkan keadaan geografis yang sesuai dengan kondisi tanah yang gersang dan berbatu, masyarakat desa ini berprofesi sebagai petani dengan memilih tanaman palawija sebagai komoditas utamanya. Hanya sebagian kecil saja yang menanam padi. Jenis palawija yang ditanam antara lain kacang tanah, jagung, dan ubi kayu. Masyarakat Prunggahan Kulon di samping peduli pada bidang pertanian sebagai aktivitas sosial ekonomi juga peduli dengan bidang seni dan budaya. Bentuk kesenian tradisi seperti Sindir atau Tayub merupakan jenis kesenian yang sudah tidak asing lagi bagi masyarakat desa ini. Sindir tersebut merupakan jenis kesenian yang digemari hampir secara umum oleh masyarakat Prunggahan Kulon.

Setiap setelah panen padi, dipastikan ada yang nanggap atau mementaskan Sindir. Selain Sindir jenis kesenian tradisional yang masih lestari adalah Sandur. Kesenian Sandur Prunggahan Kulon terdapat di Dukuh Randu Pokak. Sandur Randu Pokak merupakan salah satu kesenian yang masih dilestarikan keberadaan dan orisinalitasnya. Secara khusus, Sandur dilestarikan oleh Kelompok Turangga Budaya. Keberadaan kelompok ini menunjukkan bahwa masyarakat Randu Pokak sangat peduli dengan nilai-nilai tradisi warisan leluhur. Selain faktor tersebut, keberadaan seni Sandur tidak dapat dipisahkan dengan pertanian. Masyarakat agraris adalah awal pencipta dan pengembang kesenian Sandur. Hal ini dapat dilihat dari bentuk dan isi pertunjukan Sandur yang sarat dengan idiom-idiom pertanian. Sebagai representasi atas latar belakang sosiokultur masyarakat pendukungnya, Sandur Randu Pokak banyak menggunakan bentuk-bentuk aktivitas keseharian dalam pertanian sebagai sarana pertunjukannya. Seperti dalam lakon Pethak ngenger, terdapat adegan Ngrakal atau membajak sawah yang dimainkan bersama dengan Balong yang memerankan tokoh sapi dan Pethak sebagai pembajaknya.

\section{Bentuk Pertunjukan Sandur Randu Pokak}

Pertunjukan kesenian Sandur di Pedukuhan Randu Pokak Desa Prunggahan Kulon Kecamatan Semanding Kabupaten Tuban ini membutuhkan waktu selama sembilan jam, dimulai dari pukul 20.00 hingga 04.00. Seperti halnya pada Sandur Bojonegoro, pertunjukan Sandur Randu Pokak dibagi menjadi dua bagian, yakni bagian prapertunjukan dan bagian pertunjukan. Sebelum pertunjukan dimulai, dilangsungkan ritual Setren/Nyetri yang memiliki fungsi dan tujuan sama dengan pola pendhanyangan yang ada di Bojonegoro. Di dalam tradisi Sandur Randu Pokak, ritual Setren dilakukan secara bersama dengan seluruh pendukung pertunjukan dipimpin oleh Germo. Ritual ini dilakukan dengan cara mendatangi Grumbul atau tempat keramat yang ada di sekitar tempat pertunjukan akan digelar dengan berjalan kaki. Biasanya ritual ini dilakukan sehari sebelum waktu pertunjukan. Di daerah 
Randu Pokak, tempat yang biasa digunakan untuk melakukan Setren adalah di Kuburan Gembul, yaitu tempat pemakaman umum yang ada di dukuh ini. Pelaksanaan ritual ini tidak memiliki ketentuan khusus perihal tentang pilihan harihari tertentu dan tidak ada semacam larangan atau syarat khusus dengan waktu pe-nyetrenan.

Tahap berikutnya setelah ritual Setren dilaksanakan adalah menyiapkan sarana pertunjukan. Sebelumnya, dilakukan ritual slametan yang dipimpin oleh Tukang Tanduk. Ritual ini dilakukan dengan membacakan doa khusus dengan tujuan agar dalam rangka mempersiapkan sarana atau arena pertunjukan dapat berjalan lancar. Pada ritual ini dilakukan pembakaran merang (tangkai padi kering) dilengkapi dengan membawa sajen yang terdiri dari aneka makanan seperti gedhang raja, gedhang pulut, tumpeng, ketan tawa, cok bakal, endog, kupat lepet, kendi dan jebor. Setelah acara slametan selesai, dilanjutkan dengan memasang segala sarana kebutuhan pentas. Sarana dipersiapkan sebelum pentas dimulai antara lain pemasangan kentheng (tali pembatas arena pertunjukan), rontek, bambu dan tali untuk adegan kalongking, properti dan instrumen musik pengiring serta sesaji. Setelah seluruh kelengkapan pertunjukan telah dipersiapkan, pada malam harinya dilaksanakan pertunjukan secara menyeluruh.

Rangkaian berikutnya adalah tahap pertunjukan. Pertunjukan dipimpin oleh Germo dan dimulai dengan adegan gambuhan, yakni adegan pembuka dengan melantunkan tetembangan bersama Panjak Hore. Tembang pembuka adalah tembang Semelah/Bismillah, kemudian dilanjutkan dengan tembang Kapuk Uluk yang berisikan tentang proses mencari tempat untuk pertunjukan. Setelah itu dilanjutkan dengan tembang Kembang Tok yakni tembang saat masang pathok, kemudian tembang kembang Theleng yakni tembang saat memasang kentheng (tali pembatas pentas). Selanjutnya tembang Kembang Singkil yakni tembang tentang memasang Khathil (kursi/bangku), kemudian tembang Kembang Nongko, yakni tembang saat memasang Mejo (meja), dilanjutkan dengan tembang Kembang
Wijen yakni tembang saat memasang Sajen (sesaji), kemudian tembang Kembang Wuring yakni tembang saat memasang Pring (bambu). Setelah itu dilantunkan tembang Kembang Abang yakni tembang saat memasang Kembang Mayang, dilanjutkan dengan tembang Kembang Blutru saat memasang lampu, lalu Kembang Abang saat memasang Kendang, kemudian yang terakhir tembang Kembang Theleng saat memasang Gong Gumbeng (Gong bambu). Setelah selesai melantunkan tembang tersebut, ditutup dengan tembang Kembang Sigo Gori yang berisi tentang jumlah Panjak Sandur yang terdiri dari dua belas orang. Adegan Njaluk Idi dilangsungkan setelah menyanyikan tembang Kembang-kembangan seperti tersebut di atas, kemudian dilanjutkan dengan tembang Kembang Cerme yang berisikan tentang meminta ijin atau Uluk Salam kepada Dhanyang tempat diselenggarakannya pentas. Pada Sandur Randu Pokak, dimintakan ijin kepada Dhanyang Telon Wiyu yang dipercaya oleh masyarakat sebagai sang mbahureksa daerah tersebut. Tembang ini memiliki tujuan agar setelah dilantunkan seluruh pendukung pertunjukan mendapat restu dan berdoa agar terhindar dari sengkala atau marabahaya yang mungkin terjadi selama pertunjukan berlangsung.

\section{Komparasi Pertunjukan Sandur Bojo- negoro dan SandurTuban}

Soedjono (1994: 313) berpendapat bahwa perbandingan bentuk bertujuan untuk mengetahui koherensi, masing-masing bagian dan unsurunsurnya dapat dipahami keberadaannya dengan jelas dan dalam konteks keberadaan struktur bentuknya secara keseluruhan dan korespondensi, yakni adanya hubungan timbal balik antara subjek dan bentuknya yang bersifat internal dan eksternal dalam menciptakan suatu kesatuan penampilan bentuk yang harmonis. Unsur-unsur yang dianalisis adalah tema cerita, pemain, pola permainan, tata rias dan busana, properti, iringan, tempat dan sarana pertunjukan, waktu penyajian dan penonton. Berikut ini adalah uraian analisis perbandingan unsur-unsur pertunjukan Sandur Bojonegoro dan Tuban. 


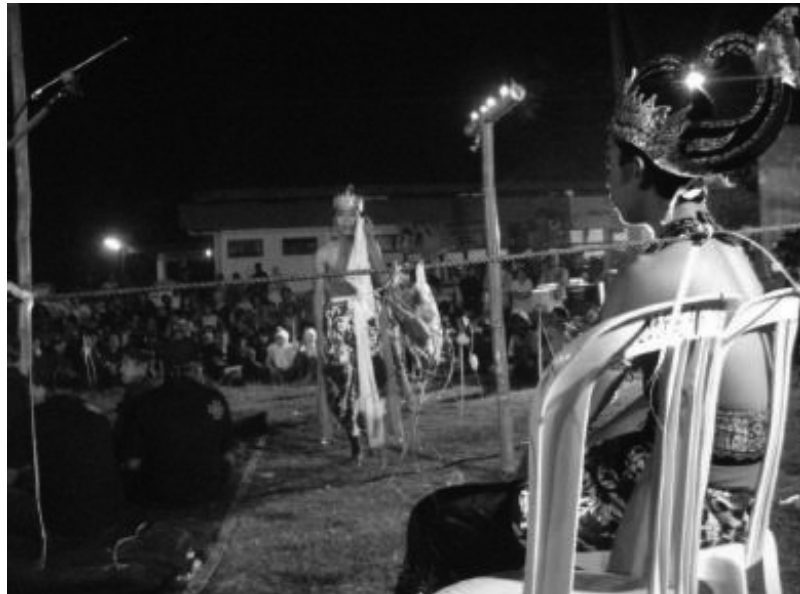

Gambar 3. Tokoh Balong Bojonegoro (Repro: Masnun, 2009).

\section{Tema}

Tema lakon pertunjukan Sandur adalah persoalan kehidupan tentang pertanian. Dalam hal ini kehidupan yang mencakup hubungan antarmasyarakat, antara masyarakat dengan individu-individu, dan antarperistiwa yang terjadi dalam batin seseorang. Lakon Sandur bercerita tentang persoalan sosial, konflik, serta peristiwa yang dapat ditemui pada kehidupan masyarakat petani misalnya, mencari pekerjaan, menggarap lahan pertanian, saling mengejek, dan kekurangan uang. Sebagai contoh adalah lakon Pethak Ngenger. Dalam lakon ini diceritakan tentang tokoh Pethak yang sedang mencari pekerjaan kepada Germo, namun Germo tidak dapat memenuhi, kemudian menyarankan pada Pethak untuk meminta pekerjaan kepada Tangsil. Di tempat Tangsil, Pethak juga tidak mendapat pekerjaan dan disarankan untuk datang kepada Balong. Akhirnya Balong yang memberikan pekerjaan kepada Pethak, yakni mencari lahan pertanian untuk bercocok tanam.

\section{Pemain}

Pada awalnya, seluruh pemain pertunjukan Sandur diperankan oleh laki- laki, namun dalam perkembangannya dapat berubah sesuai dengan kebutuhan ceritanya. Sebagai contoh, pertunjukan Sandur di Bojonegoro telah mengalami perubahan pada pola penokohannya, yaitu: tokoh Cawik pada awalnya diperankan oleh laki-laki, namun saat ini tokoh tersebut dapat diperankan oleh perempuan. Pada pertunjukan Sandur Tuban, seluruh tokoh cerita tetap diperankan oleh laki- laki hingga saat ini. Pola peran tokoh perempuan yang dimainkan

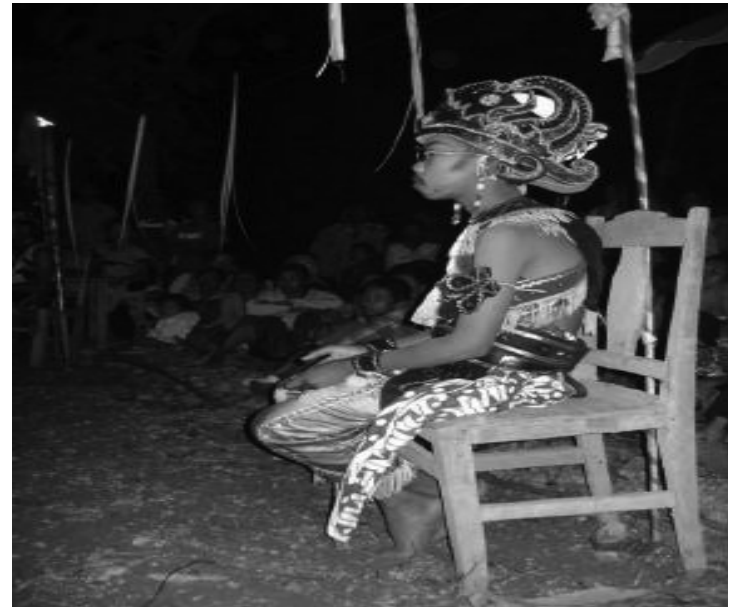

Gambar 4. Tokoh Balong Tuban (Dokumentasi: Ali As'ad, 2009).

oleh laki-laki (transvetis) pada penokohan ini dianggap sebagai peraturan yang tidak dapat diubah. Selain itu, masih dipertahankan aturan bahwa pertunjukan Sandur harus dimainkan oleh anak-anak laki-laki yang belum balig atau belum dikhitan. Menurut aturan, anak-anak ini tidak diperbolehkan khitan jika belum memainkan pertunjukan Sandur sebanyak empat puluh kali. Aturan atau pakem ini dikhususkan pada pemeran tokoh Pethak, Cawik, Tangsil, dan Balong. Empat tokoh inilah yang disebut sebagai "Sandur" dalam tradisi Sandur Tuban. Fenomena dalam mempertahankan aturan yang berlaku dalam tradisi Sandur Tuban dimaksudkan untuk menjaga kesakralan dalam setiap pertunjukannya. Keterangan tersebut menjadi faktor yang membedakan antara pola penokohan pertunjukan Sandur Bojonegoro dan Tuban. Para pelaku atau pemain pertunjukan Sandur Bojonegoro dan Tuban memiliki beberapa penokohan yang sama, yakni tokoh Germo, Pethak, Cawik, Tangsil, dan Balong.

Beberapa pemain yang sudah disebutkan di atas adalah unsur pemain yang sama-sama terdapat pada masing-masing Sandur. Selain pemain tersebut, masih ada beberapa pemain yang tidak dimiliki oleh masing-masing Sandur yang pada akhirnya dapat menjadi identitas kekhususan masing-masing. Misalnya dalam Sandur Bojonegoro terdapat Tukang Njaran, Srati, Pendhegar dan Tukang Ngalong. Demikian juga pada pertunjukan Sandur Tuban masih terdapat beberapa pelaku yang tidak ditemukan dalam Sandur Bojonegoro. Pelaku-pelaku tersebut 
adalah sebagai berikut Mantri, Waker, Nyai, Cah Angon, Kaji Nyolong Céléng, Cino Dingklang Pados Céléng, Sopir Cikar (bajingan), Juru Kunci atau tukang Tandhuk, Ketua Rombongan, Panjak Oncor (pembawa obor), Tukang Kendut dan Tukang Bancik (Bancik Endog, Bancik Kendhi, Bancik

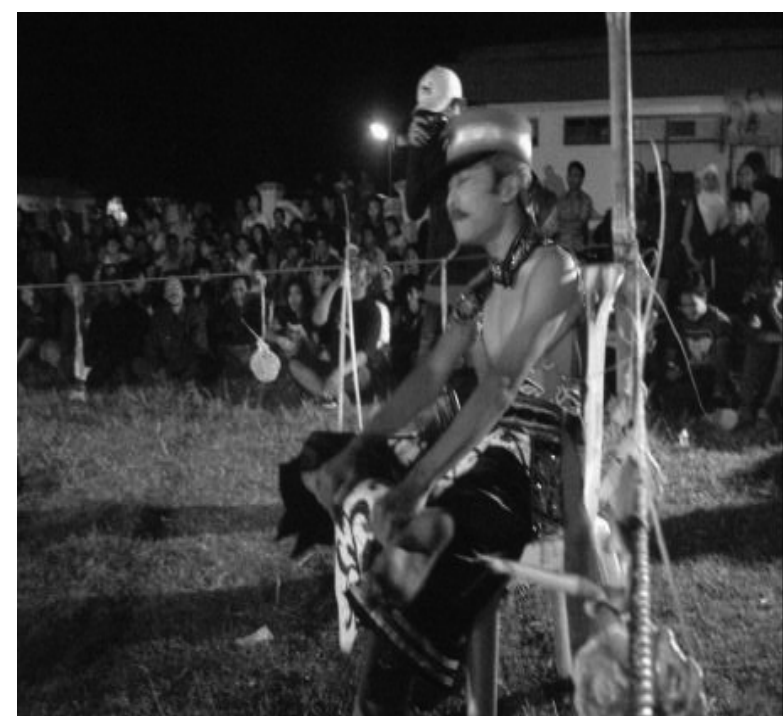

Gambar 5. Tokoh Tangsil pada Sandur Bojonegoro (Repro: Masnun, 2008)

\section{Pola permainan}

Dalam bentuk penyajiannya, pada Sandur Bojonegoro terdiri dari tiga bagian, yaitu (1) bagian pembuka, (2) bagian cerita dan (3) bagian penutup. Pada adegan pembukaan, ditandai dengan dilantunkannya tembang Ilir gantu dan para pemain mulai memasuki arena permainan. Tokoh Germo memperkenalkan tokoh satu per satu kepada penonton sampai pada pembukaan kain kerudung pada pemain. Pada bagian cerita, dikisahkan tentang perjalanan tokoh Pethak dan Balong yang tengah mencari pekerjaan. Keseluruhan cerita pada babak ini adalah perjalanan tentang kehidupan masyarakat melaksanakan proses pertanian. Pada bagian terakhir atau penutup, berisi tentang nasib akhir para tokoh pemeran. Hal ini ditandai dengan adegan atraksi kalongking. Dalam bentuk penyajiannya, pola permainan Sandur dilakukan dengan dialog dan menari. Dialog yang digunakan adalah bahasa Jawa dengan dialek Bojonegoro. Dialog dilakukan secara berulang-ulang sehingga terkesan monoton. Alat ekspresi (media ungkap)
Dhengkul, Bancik Pundhak). Pelaku Tukang Bancik Pundhak terdiri dari tiga orang sedangkan pada Bancik yang lain dilakukan oleh satu orang yang sama. Untuk adegan atraksi Kalongking dilakukan oleh empat tokoh yaitu, Pethak, Tangsil, Balong dan Cawik.

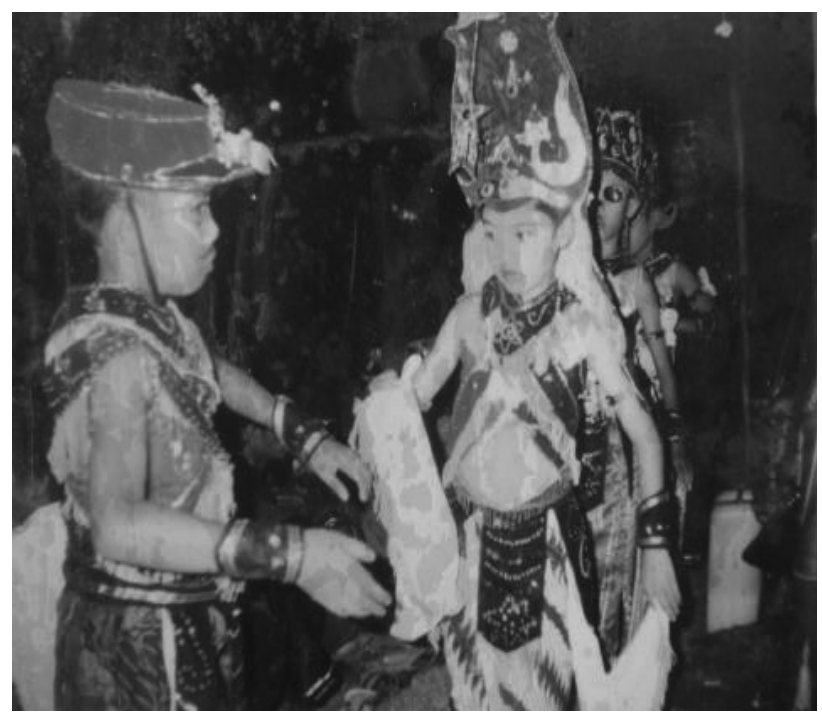

Gambar 6. Tokoh Tangsil pada Sandur Tuban (Repro: Sakrun, 2007)

yang digunakan tidak hanya dengan laku dan suara (dalam bentuk percakapan), tetapi serentak dilakukan juga dengan menyanyi dan gerak tari yang kesemuanya dipertunjukkan dengan iringan music secara terpadu. Pada Sandur Tuban, pertunjukan terdiri dari empat bagian. Bagian pertama adalah pra-pertunjukan, yaitu para panjak hore menyiapkan perlengkapan pentas dan membuat arena atau kalangan. Sebelum dilaksanakan persiapan perlengkapan pentas diadakan acara tirakatan selama tujuh hari. Acara ini dimanfaatkan oleh seluruh pendukung Sandur untuk menyiapkan ubo rampe (kelengkapan) pertunjukan. Selain itu, selama tujuh malam digunakan untuk latihan oleh para panjak dan pemeran tokoh Sandur. Bagian kedua adalah pembukaan yang diisi dengan adegan gambuhan yang dilakukan oleh tukang tandhuk, blendrongan dan selamatan dilanjutkan dengan adegan inti, yaitu golek ngengeran yang di dalamnya terdapat adegan selingan badutan kritikan sosial lalu dilanjutkan dengan atraksi kalongking. Bagian terakhir adalah penutup yang ditandai dengan gambuh oleh-oleh yang berarti kembalinya bidadari dan berakhirnya pertunjukan. 
Instrumen iringan dalam pertunjukan Sandur Bojonegoro dan Tuban cukup sederhana, yakni menggunakan sebuah kendhang batangan dan gong bumbung (bambu besar berukuran sekitar 1 meter, cara membunyikannya dengan ditiup). Selain instrumen pengiring tersebut juga terdapat tembang-tembang sebagai iringan yang dinyanyikan oleh panjak ore. Tembang-tembang yang dinyanyikan dalam pertunjukan Sandur sangat fungsional, selain sebagai pengiring keluar masuknya pemain juga berfungsi sebagai mantra pemanggil roh halus.

Seni pertunjukan Sandur biasanya dipentaskan di tempat yang luas, dapat di halaman rumah atau tempat lapang yang lain. Arena pertunjukan ini biasa disebut blabar janur kuning dalam Sandur Bojonegoro atau kalangan pada Sandur Tuban. Arena dibatasi dengan tali sebagai pagar pemisah antara pemain dan penonton. Tali pagar tersebut diberi hiasan janur kuning dan digantungi aneka jajan pasar. Selain itu, terdapat ketupat dan lepet (lonthong ketan). Sebutan blabar janur kuning berasal dari kata mblabar yang berarti tumpahan yang menyebar ke segala arah atau dapat juga berasal dari kata babar yang berarti lahir (keluar dari rahim), dalam arti secara konotatif diartikan sebagai dipaparkan atau diuraikan. Janur berasal dari jarwa dhosok; sejatining nur yang bermakna "sesungguhnya cahaya atau petunjuk" kebenaran dari Tuhan. Kuning merupakan warna yang memiliki makna simbolis yakni sebagai simbolisasi keduniawian, sebagaimana digunakan untuk nafsu supiah. Berdasarkan makna-makna kata tersebut, blabar janur kuning bermakna ajang untuk memaparkan petunjuk atau pelajaran tentang kebenaran hidup dan kehidupan dari Tuhan.

Pertunjukan Sandur Bojonegoro maupun Tuban dilaksanakan dalam dua tahap yakni prapertunjukan dan saat pertunjukan. Dalam tahap pra-pertunjukan, dilakukan prosesi ritual setren yakni proses penginapan semua properti yang dipakai dalam pertunjukan Sandur pada tempat yang dianggap keramat seperti di dalam Cungkup atau di Gerumbul. Ritual ini dilaksanakan dengan harapan agar properti tersebut mendapat efek daya magis serta mendapat berkah dan tidak mencelakai para pemain yang menggunakannya. Ritual ini dilaksanakan seminggu atau sehari sebelum pertunjukan dilangsungkan. Tradisi Sandur Bojonegoro maupun Tuban dipentaskan pada malam hari yakni dimulai pada pukul 21.00 sampai menjelang subuh. Namun pada perkembangannya, saat ini Sandur dipentaskan dengan durasi 2-3 jam saja. Sebelum pertunjukan dilaksanakan, pada siang harinya dilakukan upacara pendanyangan yaitu upacara ritual membakar kemenyan dan sesaji Cok Bakalyang dipimpin oleh Germo pada pertunjukan Sandur Bojonegoro atau oleh Tukang Tandhuk pada pertunjukan Sandur Tuban. Ritual ini dilakukan di sudut Timur Laut arena pertunjukan. Pada perkembangannya, durasi pertunjukan yang dilaksanakan dalam Sandur Bojonegoro sudah mulai berkurang. Pertunjukan dilaksanakan sesuai dengan cerita yang telah dikembangkan. Proses pengembangan cerita ini terkadang menyesuaikan dengan tujuan pentas yang akan dilaksanakan. Hal ini dapat menjadi salah satu faktor berubahnya waktu atau durasi penyajian dari semalam suntuk menjadi 2-3 jam. Selain faktor tersebut, keberadaan penonton juga menjadi perhatian pada sukses atau tidaknya suatu pertunjukan. Secara umum kehadiran dan kenyamanan penonton saat pertunjukan dapat dilihat dengan kemampuan bertahan penonton sampai akhir pertunjukan. Kenyataan yang terjadi bahwa pada saat ini penonton atau masyarakat sudah tidak betah untuk menyaksikan sebuah pertunjukan yang berdurasi lama.

\section{Penutup}

Kesenian Sandur sebagai kesenian rakyat memiliki wujud atau bentuk khas yang berdiri sendiri secara utuh. Bentuk kesenian tersebut dapat dinilai melalui analisa unsur-unsur yang terdapat di dalamnya. Proses analisis ini berupaya untuk menelaah secara mendalam tentang elemen-elemen yang terdapat dalam bentuk pertunjukan Sandur. Pengkajian pertunjukan Sandur Bojonegoro dan Tuban dalam konteks perbandingan ini bertujuan untuk menganalisa unsur-unsur pembentuk kesenian tersebut pada dua daerah yang berbeda, yaitu pada tema cerita, pemain, dan pola permainan pertunjukan Sandur Bojonegoro dan Tuban. Hasil dari analisis yang telah dilakukan menunjukkan adanya persamaan dan perbedaan unsur-unsur pertunjukan Sandur di Bojonegoro dan Tuban. Dengan demikian, kajian perbandingan seni merupakan unsur penting dalam upaya penelaahan karya seni secara utuh. Karya seni yang diperbandingkan 
perlu mendapatkan perhatian khusus sebagai media yang akan menghantarkan pada proses pemahaman terhadap nilai-nilai yang terkandung di dalamnya.

\section{Kepustakaan}

Havilan, William A. 1988. Antropologi, terjemahan RG. Soekadijo. Jakarta: Erlangga.

Kasim, Ahmad. 1981. Teater Rakyat di Indonesia; Analisis Kebudayaan. Jakarta: DIRJEN P\&K. 1986. "Teater Tradisional Sebagai Sumber Kajian Bagi Perkembangan Teater Modern”, dalam Menengok Tradisi; Sebuah Alternatif Bagi Teater Indonesia. Jakarta: Dewan Kesenian Jakarta.

Monografi Desa Ledok Kulon, Bojonegoro, Jawa Timur, Tahun 2008-2009.
Sedyawati, Edi. 1981. Pertumbuhan Seni Pertunjukan. Jakarta: Sinar Harapan.

Soedarsono. 2001. Seni Pertunjukan Indonesia di Era Globalisasi. Yogyakarta: Gadjah Mada University Press.

Soedjono, Soeprapto. 1994. Fenomena Bentuk Estetik Dalam Studi Perbandingan Seni, dalam Jurnal SENI, volume IV/ no 04 Oktober.

Winarti. 2005. "Makna Simbolis Pertunjukan Sandur Desa Ledok Kulon Kecamatan Bojonegoro Kabupaten Bojonegoro Jawa Timur", Skripsi S-1 Jurusan Tari, Fakultas Sen Pertunjukan, Institut Seni Indonesia Yogyakarta.

\section{Narasumber}

Jagad Pramudjito, 53 tahun, seniman sandur, Bojonegoro. 